\title{
THE TREATY OF WAITANGI AND THE CONTROL OF LANGUAGE BY RICHARD DAWSON
}

\author{
Reviewed by Joss Opie*
}

Richard Dawson The Treaty of Waitangi and the Control of Language (Institute of Policy Studies, Wellington, 2001). Paperback, 255 pages, \$NZ29.

\section{THE TREATY OF WAITANGI AND THE CONTROL OF LANGUAGE}

Richard Dawson's The Treaty of Waitangi and the Control of Language explores how particular interpretations of the Treaty of Waitangi (the Treaty) have been empowered while others have been marginalised. His focus is on "conflicting interpretations given to the Treaty and the process by which certain interpretations have been made to count."1 He argues that interests are made to count through law, by being transformed into legally endorseable rights. As law is comprised of words, the control over the meaning and significance of certain words creates the ability to prioritise certain interests over others. Dawson proposes that such control resides in the holders of sovereignty in a society. Because Maori have been effectively excluded from shaping the sovereign will in New Zealand, they have had little control over determinations as to how law will affect them, and particularly to what extent law will recognise Treaty guarantees. Dawson sees this lack of power over language as a major factor in Maori dispossession.

Dawson views sovereignty as an "object of use" 2 to distribute power. What is crucial for Dawson is how this distribution occurs, and thereby which actors are marginalised or favoured. He proposes that law is a system which distributes power among a number of actors who exist in corresponding relationships to one another. He uses a Hohfeldian

* Honours Student, Victoria University of Wellington.

1 Richard Dawson The Treaty of Waitangi and the Control of Language (Institute of Policy Studies, Wellington, 2001) 228.

2 Dawson, above n 1,38 . 
analysis to illustrate this proposition. ${ }^{3}$ For example, where Party A has a liberty (a legally endorsed right to do something) Party B is exposed; B cannot legally object to A's conduct. The notion of immunity and disability is also important. An immunity exists for A where A's legal relations cannot be changed by B, who then is seen as having a disability. Therefore, Dawson sees legally endorseable rights as creating advantages and disadvantages; the allocation of rights will place certain members of society in a position of inequality with other members. As the content of those liberties and immunities is determined by law, the ability to both make and interpret law is vital. Possessing the power to imbue language with legal significance, and determine the extent of that significance, or lack thereof, allows control to be gained over the determination of "whose interests are to be elevated to the status of protected rights and whose interests are to be renounced." 4

Using this analysis, Dawson evaluates "antecedents" to the Treaty, such as the 1785 Treaty of Hopewell between the United States Government and the "Cherokee Nation." He explores the history of litigation surrounding the Treaty of Hopewell to demonstrate how the lack of control by the Cherokee over the "language" that bound them led to their dispossession. Dawson describes how the Cherokee, being unable to back their asserted rights with force, had to resort to "words" to drive their claim within the foreign institutions and structures of the United States Government. This left them critically disadvantaged, as they could not control the content, interpretation or application of the laws the United States Government held them to be bound by. ${ }^{5}$

From that basis, Dawson provides a discussion of Treaty jurisprudence to essentially illustrate the same proposition. He argues that Maori exclusion from the colonial systems of power meant that their interpretations of the Treaty of Waitangi, and their assertions as to the rights the Treaty entitled them to, were able to be discounted. The Crown, as the holders of sovereignty, determined the significance, or lack thereof, of the Treaty; its interpretations of Treaty "words" were backed with legal power.

Dawson argues that a Crown monopoly over language continues today. The Sealord Deal, the establishment of an individual transferable quota system, and the Waitangi Tribunal are described as processes in which the Crown set the parameters and chose which Maori groups or individuals it would empower. Final outcomes are seen as dominated by the Crown, with it being the sole body capable of bestowing legitimacy on

3 Dawson, above n 1, 16. This chapter also provides discussions of a number of other concepts, such as Commons' "Reasonable Value" and his "Joint Words-Rights Determination Process".

4 Dawson, above n 1, 228.

5 Dawson, above n 1, 56. 
any resolution. The Crown had, and still has, the "power to determine which labels and categories matter". 6

Although Dawson states that his project is predominantly non-normative, he proposes the creation of institutional structures to enable Maori to participate in a balanced (in the sense of a rough equality of power) dialogue with the Crown. Dawson outlines what he calls a "Language Forum" which would be an institution to directly address linguistic issues relating to the Treaty. This "forum", Dawson suggests, with equal Maori/Pakeha representation "would provide an element of linguistic cultural equality between representatives of the parties to the Treaty that simply has not existed since the 1860s."7 Such a project would be a starting block, to raise awareness about divergent opinions on the status of the Treaty, without one party being automatically placed in a dominant position over the other.

\section{PROBLEMS WITH DAWSON'S APPROACH}

Dawson states that a central aim of his book is to "comprehend and illuminate essential issues and processes in the operation of legal institutions of economic significance." 8 However, in focussing only upon the "legal-economic nexus" ${ }^{9}$, Dawson in fact overlooks some critical issues. He tends to cast all power relationships between the Crown and Maori in a binary, have/have-not relationship. Dawson appears to see power as residing exclusively in the sovereign, including the power to control language, whereas Maori are placed in a position outside power. This description of power is problematic.

A Foucauldian analysis of power ${ }^{10}$ holds that there is no position outside of power. Institutions such as sovereignty are only the terminal forms that power takes; power itself is generated from the bottom-up, not the top-down. Conglomerations of power are unstable, and their existence exposes them to resistance. Resistance, itself a form of power, modifies and challenges the hegemonic concentrations. Foucault cautions against a model which simply divides discourse into accepted discourse and excluded discourse; he sees a multiplicity of discourses at work within a society, which attack and can modify or even ultimately thwart the dominant discourse.

\footnotetext{
6 Dawson, above $\mathrm{n} 1,151$.

7 Dawson, above $\mathrm{n} 1,224$.

8 Dawson, above n 1, 228.

9 Dawson, above $\mathrm{n} 1,228$

10 Michel Foucault The Will to Knowledge- The History of Sexuality: Volume 1 (Penguin Books, England, 1998)
} 
In the writer's view, Dawson's binary models of advantage and corresponding disadvantage struggle to cope with the complexity of relations between what can loosely be called "the Crown" and "Maori" as they change over time. Dawson's analysis seems to move seamlessly from Prendergast CJ's determination of the Treaty as a legal nullity ${ }^{11}$ to fisheries negotiations to the 2000 Building the Constitution conference where the Treaty was "by far the most pervasive theme."12 Dawson's account presumes that, because sovereignty (a term which he does not define) has remained in the Crown, power relations between Maori and the Crown have also remained essentially the same. This cannot be true, for the position that the Treaty occupies in current New Zealand society is significantly different from that in Prendergast CJ's New Zealand. The existence of the Waitangi Tribunal, the Office of Treaty Settlements, and the fact that the Treaty was a very significant part in a conference entitled Building the Constitution, is clear evidence of this. While power relations between the Crown and Maori have not been reversed, or even equalised, real change has occurred. How has this happened, if control over language has remained exclusively in the hands of the Crown?

Dawson's point that language can be and is manipulated by powerful groups within a society to benefit certain interests is indisputable. However, the identities of those groups, their interests and their emphasis do not remain static. Entities such as "the Crown" and "Maori" are not fixed institutions, but fluid categories which have changed over time. They cannot be described merely as opposing forces; both have influenced the other and both have changed the other. For example, the comparatively extensive use of the Maori language in government departments and publications, when compared to colonial monolingualism, demonstrates this influence.

By focussing on the sovereign as the source of power, as opposed a terminal concentration of power, Dawson risks neglecting an essential issue in the control of language: how is it that multiple Maori groups and other resistances, despite their apparent lack of formal power, have changed the dominant discourse regarding the Treaty? How has language been altered over time to move the Treaty from a position of

11 In Wi Parata $v$ Bishop of Wellington (1887) 3 NZ Jur (NS) 72, 78 (SC) Prendergast CJ stated that "so far as it purported to cede sovereignty... [the Treaty] must be regarded as a simple nullity." He concluded that the "natives" were incapable of ceding sovereignty, as they lacked civil government, and that New Zealand was an "uninhabited territory" in the eyes of the law. Morag McDowell and Duncan Webb The New Zealand Legal System: Structures, Processes and Legal Theory (Butterworths, Wellington, 1995) 196.

12 Dawson, above $\mathrm{n} 1,186$. 
complete disregard to, in Dawson's words, "a prominent place in legal-economic policymaking in New Zealand."? ${ }^{13}$

The Treaty of Waitangi and the Control of Language offers an interesting new perspective for looking at conflicts surrounding the interpretation of the Treaty. By utilising such a perspective and broadening its scope, we can gain significant further insight into the continuous reconstitution of the Crown-Maori relationship, and New Zealand society.

13 Dawson, above $\mathrm{n}$ 1, blurb. 